\title{
A STUDY ON THE DIAGNOSIS OF MINIMAL ENDOSCOPIC LESIONS IN NONEROSIVE REFLUX ESOPHAGITIS USING COMPUTED VIRTUAL CHROMOENDOSCOPY (FICE)
}

\author{
Claudio Antonio Rufino GOMES Jr., Thais Santana LOUÇÃO, Glaucia CARPI and \\ Wilson Roberto CATAPANI
}

\begin{abstract}
Context - Gastroesophageal reflux disease is very prevalent in the world. Endoscopically it can be classified as nonerosive when there is no mucosal erosive lesion on endoscopy. The presence of endoscopic minimal lesions is included in the Los Angeles classification for reflux disease. Virtual chromoendoscopy Fuji Intelligent Color Enhancement (FICE) is an endoscopic technique that enhances detection of small lesions of the digestive tract. Objective - To evaluate whether the use of FICE improves the diagnosis of minimal lesions on endoscopy, and to assess the association of symptoms with minimal lesions in patients with nonerosive reflux disease. Methods - One hundred fiftyfive patients were enrolled, 62 with typical reflux symptoms and 93 without esophageal symptoms. The patients had normal esophageal endoscopy or minimal lesions. Each patient was examined initially by conventional video endoscopy and then using FICE. Results - Among 155 patients, 113 had a normal conventional endoscopy and 42 had minimal lesions. Sixty-two patients had typical reflux symptoms, and 93 other symptoms unrelated to reflux. In 104 patients, the esophageal mucosa was normal for both conventional endoscopy and FICE, in 42 patients both techniques showed minimal lesions, in 9 patients conventional endoscopy was normal and minimal lesions were shown by FICE. The height and circumference of minimal lesions were greater using FICE than that measured by conventional endoscopy. There was a significant association of the presence of minimal lesions with male gender, but not with alcoholism, smoking, anti-inflammatory drugs and age. The diagnosis of minimal lesions was observer-dependent, both in conventional endoscopy as using FICE. Conclusions The use of FICE improves the diagnosis of minimal lesions as compared to conventional videoendoscopy, although this diagnosis remains observer-dependent. There was no association between the presences of minimal lesions with reflux symptoms.
\end{abstract}

HEADINGS - Gastroesophageal reflux. Esophagitis, peptic. Endoscopy. Diagnosis, computer-assisted.

\section{INTRODUCTION}

In recent years, several novel imaging techniques have been developed and refined for digestive endoscopy in an effort to detect smaller lesions and allow earlier diagnosis and more effective treatment ${ }^{(3)}$.

Currently available endoscopy techniques range from conventional modalities of visualization to devices enabling image magnification. A recently developed system is that of computed virtual chromoendoscopy. This is a novel technique which enhances mucosa surface structures and improves visualization of veins. The system was developed by the Fujinon Co. (Japan) and is thus also known as Fuji Intelligent Color Enhancement (FICE). The technique is based on the selection of spectral transmittance with a dedicated wavelength ${ }^{(2,6)}$.
Gastroesophageal reflux disease (GERD) is one of the most prevalent gastrointestinal diseases, with a prevalence of 10\%-20\% in Western Europe and North America $^{(4,11)}$. In Brazil, large populational studies showed a prevalence of heartburn once a week around $12 \%$ and more than once a week $7.7 \%{ }^{(9)}$. According to the Montreal consensus, GERD is a symptom-based diagnosis: patients with GERD are those in who reflux of gastric contents cause troublesome symptoms or complications. Nonerosive reflux disease is defined by the presence of troublesome reflux-associated symptoms and the absence of mucosal breaks at endoscopy ${ }^{(12)}$.

An estimated $50 \%$ of patients with typical GERD complaints in tertiary centers and only $30 \%$ in primary practice will have erosive esophagitis, most of these will present either a normal endoscopy or criteria for minimal endoscopic lesions (MEL) ${ }^{(5)}$. In Japan,

Conflicts of interest: none

Fujinon Co. was not involved in any kind of sponsorship related to this work.

Gastroenterology Section, Faculdade de Medicina do ABC (FMABC) - Santo André, SP, Brazil.

Correspondence: Dr. Claudio A. R. Gomes Jr - Rua Xingu, 175 - apt. 51 - 09060050 - Santo André, SP, Brazil. E-mail: rufinogomes@terra.com.br 
modification of the conventional Los Angeles classification was proposed, to incorporate these minimal endoscopic lesions, namely: edema, erythema, nacreous mucosa or destruction of blood vessels, by adding the grades $\mathrm{N}$ (normal mucosa) and $\mathrm{M}$ (in the presence of the lesions listed) $)^{(6,8)}$. Virtual chromoendoscopy is believed the optimal technique for assessing such minimal lesions ${ }^{(3)}$.

The primary goal of this study was to assess the effectiveness of FICE for diagnosing esophageal MEL when compared to conventional videoendoscopy (CVE). As a secondary objective, we assessed the association of MEL with reflux symptoms, controlling for other parameters such as use of nonsteroidal anti-inflammatory drugs (NSAIDs), etilism, tabagism, age and gender.

\section{METHODS}

Two hundred twenty-four patients referred for endoscopy in a primary care outpatient clinic who where invited to take part and signed a free and informed consent term, previously approved by the Research Ethics Committee of the Faculdade de Medicina do ABC, Santo André, SP, Brazil (protocol number 065/2009).

The subjects were interviewed prior to the endoscopic examination, fulfilling a questionnaire about demographic data, symptoms of pyrosis/regurgitation, tabagism, etilism, and use of medications. The patient then proceeded to endoscopy. The endoscopist was blind to the patient's data. The results of endoscopy were immediately reported to the interviewer, and patients with a diagnosis of erosive lesions, or having a full or partial esophagectomy, those who presented stenotic lesions, alterations which hampered the assessment of esophageal mucosa (such as varices or moniliasis), those who presented agitation during the exam precluding an adequate assessment were excluded from the study. In this way, 155 patients comprised the final sample, being 62 patients with and 93 patients without reflux symptoms, and having either a normal endoscopy or MEL.

The examinations were performed by five experienced endoscopists. Each patient had the esophagus examined for at least 1 minute using CVE and immediately thereafter using FICE (Fujinon EPX-4400) for a further 1 minute or more. Channel 4 was selected because it is generally deemed the best wavelength for this assessment $t^{(1,3)}$. The length and circumference of lesions were measured both with and without FICE. MEL lesions were always located adjacent to the gastroesophageal junction.

The standard sedation regimen was administration of midazolam associated with fentanyl chlorohydrate. Additional doses of propofol were given when patients did not attain the appropriate level of sedation.

\section{Statistical analysis}

The association of the diagnosis of minimal lesions, either on CVE or using FICE, with age (under or over 40), use of NSAIDs, tabagism, etilism, use of proton pump inhibitor (PPIs), reflux symptoms, or the endoscopist who performed the exam, was examined using univariate and multivariate logistic regression technique.

The comparison between the length of MEL measured on CVE or FICE was performed by the Wilcoxon sign rank test, as well as the comparison between the percentage of the esophageal circumference occupied by the lesion on CVE and FICE.

The frequency of MEL diagnosed with or without FICE was analyzed using the McNemar test.

The $P$ value $\leq 0.05$ was used for all tests.

\section{RESULTS}

Among the 224 patients examined, 42 had MEL at endoscopy (18.7\%), 69 had erosive lesions and other exclusion criteria $(30.8 \%)$, and 113 had a normal endoscopy of the esophagus (50.4\%).

Among the 155 patients included in the study (mean age $47.0 \pm 14.6$ years, range 17-81), being 117 females and 38 males, 113 had a normal endoscopy by CVE, and 42 had MEL. Sixty-two patients had typical pyrosis or regurgitation complaints $(40 \%)$, whereas $93(60 \%)$ had other symptoms not related to reflux.

Among the 155 patients, in 104 both CVE and FICE had concordant results showing a normal mucosa, in 42 both techniques were concordant in showing MEL. Nine patients in whom a normal result was given by CVE showed MEL when examined with FICE. No patient was diagnosed as normal by FICE and having MEL by CVE (Table 1).

TABLE 1. Comparative analysis of endoscopic assessment for presence of MEL with and without use of FICE

\begin{tabular}{lcc}
\hline & Positive on FICE & Negative on FICE \\
\hline Positive on CVE & 42 & 0 \\
Negative on CVE & 9 & 104 \\
\hline$P$
\end{tabular}

$P=0.007$ (McNemar test)

MEL $=$ minimal endoscopic lesion

$\mathrm{CVE}=$ conventional videoendoscopy

FICE $=$ Fuji Intelligent Color Enhancement

Thus, among 113 patients having a normal endoscopy by CVE, 9 patients $(7.96 \%)$ showed MEL when examined by FICE.

Concerning the percentage of the esophageal circumference occupied by the lesion, on CVE the mean percentage was 53.8 $\forall 41.1$ percent, whereas on FICE it was $71.1 \forall 33.2$ percent $(P=0.0012,-$ Wilcoxon sig rank test $)$.

The length of lesions was also greater when using FICE $(1.44 \forall 1.78 \mathrm{~cm}$ on CVE and $2.48 \forall 2.16 \mathrm{~cm}$ with FICE), $P<0.0001-$ Wilcoxon sig rank test.

\section{Association of MEL with other variables}

There was no association between the diagnosis of MEL either on CVE or FICE, and age (under or over 40), use of NSAIDs, tabagism, etilism, use of PPIs, and reflux symptoms (Table 2). 
Gomes Jr CAR, Loução TS, Carpi G, Catapani WR. A study on the diagnosis of minimal endoscopic lesions in nonerosive reflux esophagitis using computed virtual chromoendoscopy (FICE)

TABLE 2. Frequency of reflux symptoms related to endoscopic findings either on conventional light videoendoscopy or FICE

\begin{tabular}{lcc}
\hline Reflux symptoms & MEL present & MEL absent \\
\hline Present & 17 & 45 \\
& $(21)$ & $(41)$ \\
Absent & 25 & 68 \\
& $(30)$ & $(63)$ \\
\hline
\end{tabular}

Numbers in brackets indicate use of FICE

Chi square $=0.01, P=0.9 ; 95 \%$ confidence limits $0.5-2.2$ (conventional endoscopy) Chi square $=0.001, P=1.0 ; 95 \%$ confidence limits $0.5-2.2$ (FICE)

$\mathrm{MEL}=$ minimal endoscopic lesion

FICE $=$ Fuji Intelligent Color Enhancement

A significant association was disclosed between gender and the diagnosis of MEL, being this more frequent in males than in females (odds ratio $4.1, P<0.001,95 \%$ CI $1.9-8.9$ for CVE/odds ratio $4.2, P<0.001,95 \%$ CI 1.9-9.0 for FICE).

The diagnosis of MEL was also associated with the endoscopist who performed the examination. There was no difference between endoscopists 1,2 and 3, whereas endoscopists 4 and 5 were about 30\%-40\% less likely to identify MEL both on CVE or FICE (Table 3).
DISCUSSION

FICE represents one of the novel methods available for detecting smaller lesions of the gastrointestinal tract, including early lesions. Recent studies have reported the effectiveness of virtual chromoendoscopy in diagnosing neoplasia in Barrett's esophagus, which has been shown to be as effective as conventional chromoendoscopy with acetic acid ${ }^{(3,10)}$.

Our data showed a prevalence of MEL of $27 \%$ among the 155 patients studied. However, these figures may not be exact, since the diagnosis of MEL was observer-dependent. This is in accordance with the previous findings of Japanese studies which showed that the interobserver agreement concerning the diagnosis of MEL is very poor ${ }^{(5,8)}$. Although there was a good agreement between CVE and FICE for each individual examiner, the odds of MEL diagnosis between endoscopists 1, 2 and 3 was significantly different from endoscopist 4 (on CVE), and endoscopists 4 and 5 (on FICE).

Our results found $\mathrm{FICE}$ to be more effective in diagnosing MEL than was CVE, whereby FICE identified around $8 \%$ more cases, with improved demonstration of the lesions in length and circumference (Figures 1 and 2).

TABLE 3. Association between endoscopists and the diagnosis of MEL on CVE and FICE by univariate logistic regression

\begin{tabular}{|c|c|c|c|c|c|c|}
\hline \multirow{2}{*}{ Endoscopist } & \multirow{2}{*}{ Odds Ratio } & CVE & \multirow{2}{*}{$\begin{array}{c}95 \% \text { confidence } \\
\text { interval }\end{array}$} & \multirow{2}{*}{ Odds Ratio } & FICE & \multirow{2}{*}{$\begin{array}{c}95 \% \text { confidence } \\
\text { interval }\end{array}$} \\
\hline & & $P$ value & & & $P$ value & \\
\hline 2 & 0.5 & 0.30 & $0.1-1.9$ & 0.4 & 0.1 & $0.1-1.4$ \\
\hline 3 & 0.3 & 0.061 & $0.1-1.1$ & 0.5 & 0.2 & $0.2-1.4$ \\
\hline 4 & 0.4 & 0.049 & $0.1-1.0$ & 0.4 & 0.036 & $0.1-0.9$ \\
\hline 5 & 0.4 & 0.1 & $0.1-1.3$ & 0.3 & 0.042 & $0.07-1.0$ \\
\hline
\end{tabular}

Odds ratios in relation to endoscopist 1

MEL $=$ minimal endoscopic lesion

$\mathrm{CVE}=$ conventional videoendoscopy

FICE $=$ Fuji Intelligent Color Enhancement

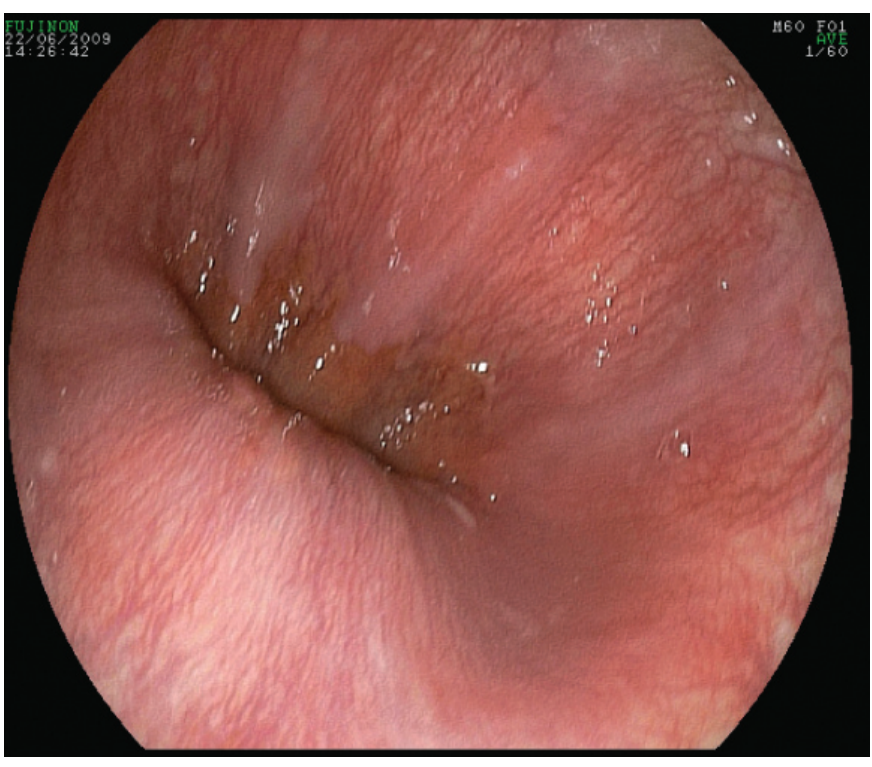

FIGURE 1. Conventional videoendoscopy showing zones of nacreous mucosa with loss of the usual vascular pattern

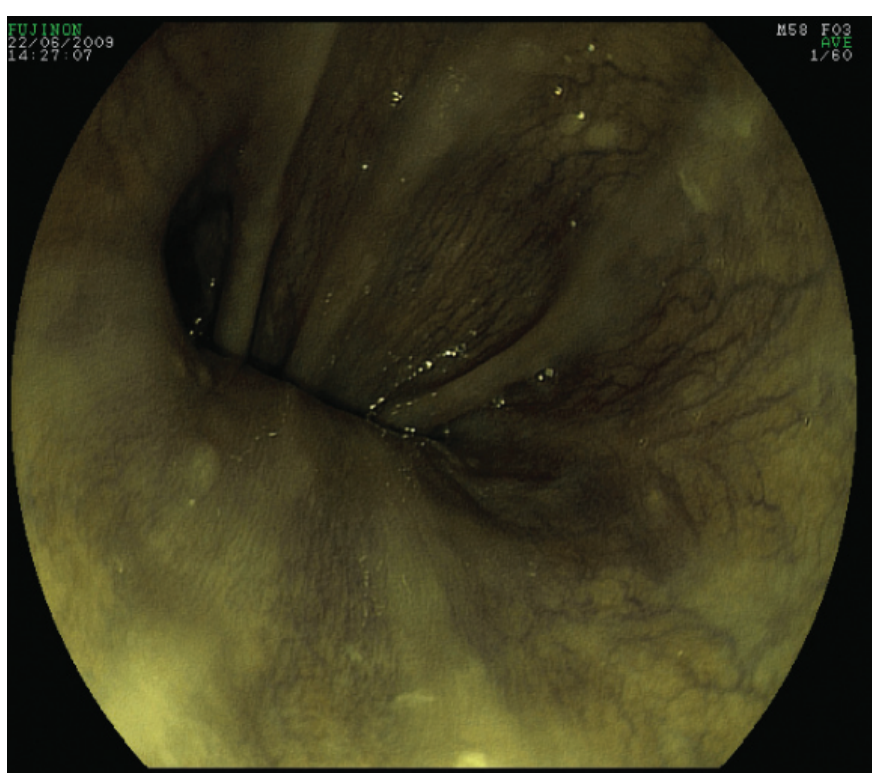

FIGURE 2. The same patient seen in Figure 1. MEL lesion (nacreous mucosa visualization) enhanced by FICE $\mathrm{MEL}=$ minimal endoscopic lesions

FICE $=$ Fuji Intelligent Color Enhancement 
A limitation of our study is the fact that the sequential observation by the same endoscopist, first using CVE than switching to FICE, could introduce some bias. However a single endoscopist worked in the endoscopy room each day, a second examiner was not available concomitantly to opine in a blind fashion about the visualization of the esophagus using FICE.

A Korean study showed an association between male gender, presence of hiatus hernia, heartburn, regurgitation and the presence of minimal changes at endoscopy ${ }^{(7)}$. Among the factors investigated in our study, no association was disclosed between age, use of NSAIDs, tabagism, etilism and reflux symptoms. Only male gender was associated with the presence of MEL (odds ratio $4.1 P<0.001$, 95\% confidence interval 1.9-8.9 on CVE, and very similar numbers for FICE).

In conclusion, although the frequency of MEL diagnosis was slightly greater using FICE than CVE, there is a significant interobserver variation in this diagnosis using both techniques. The use of FICE instead of CVE was not capable to improve any association between reflux symptoms and the presence of MEL.

\section{ACKNOWLEDGEMENTS}

We are very indebted to Drs. Durval Pessotti, Mauro Lamelas, Caio LoTurco and Ernesto Teshima for performing endoscopic examinations.

Gomes Jr CAR, Loução TS, Carpi G, Catapani WR. Estudo sobre o diagnóstico de lesões endoscópicas mínimas na esofagite de refluxo não-erosiva usando cromoendoscopia virtual (FICE). Arq Gastroenterol. 2011;48(3);167-70 .

RESUMO - Contexto - A doença do refluxo gastroesofágico é muito prevalente no mundo. Endoscopicamente pode ser classificada como não-erosiva quando não há lesões erosivas da mucosa à endoscopia. A presença de lesões mínimas à endoscopia está incluída na classificação de Los Angeles para a doença do refluxo. A cromoendoscopia virtual "Fuji Intelligent Color Enhancement" (FICE) é uma técnica endoscópica que melhora a detecção de lesões pequenas do trato digestório. Objetivo - Avaliar se o uso de FICE melhora o diagnóstico de lesões mínimas à endoscopia, e avaliar a associação de lesões mínimas com a sintomatologia em pacientes com doença do refluxo não-erosiva. Métodos - Cento e cinquenta e cinco pacientes foram incluídos no estudo, sendo 62 com sintomas típicos de refluxo e 93 sem sintomas esofágicos. Os pacientes apresentavam esôfago normal ou lesões mínimas à endoscopia. Cada paciente era examinado inicialmente pela videoendoscopia convencional e em seguida usando FICE. Resultados - Entre os 155 pacientes, 113 tiveram endoscopia convencional normal e 42 tinham lesões mínimas. Sessenta e dois pacientes tinham sintomas típicos de refluxo e 93 outros sintomas não relacionados a este. Em 104 pacientes a mucosa esofágica era normal tanto pela endoscopia convencional como pelo FICE, em 42 pacientes ambas as técnicas demonstraram lesões mínimas, em 9 pacientes a endoscopia convencional foi normal e o FICE diagnosticou lesões mínimas. A altura e a circunferência das lesões mínimas foram maiores quando observadas com FICE do que pela endoscopia convencional. Houve associação significante da presença de lesões mínimas com o gênero masculino, mas não com etilismo, tabagismo, o uso de antiinflamatórios e idade. O diagnóstico de lesões mínimas foi observador-dependente, tanto na endoscopia convencional quanto usando FICE. Conclusões - O uso de FICE melhora o diagnóstico de lesões mínimas. Entretanto, este diagnóstico é observador-dependente. Não houve associação da presença de lesões mínimas com sintomas de refluxo.

DESCRITORES - Refluxo gastroesofágico. Esofagite péptica. Endoscopia. Diagnóstico por computador.

\section{REFERENCES}

1. Amano Y, Ishimura N, Furuta K, Okita K, Masaharu M, Azumi T, Ose T, Koshino $\mathrm{K}$, Ishihara S, Adachi K, Kinoshita Y. Interobserver agreement on classifying endoscopic diagnoses of nonerosive esophagitis. Endoscopy. 2006;38:1032-5.

2. Coriat R, Chryssostalis A, Zeitoun JD, Deyra J, Gaudric M, Prat F, Chaussade S. Computed virtual chromoendoscopy system (FICE): a new tool for upper endoscopy? Gastroenterol Clin Biol. 2008,32:363-9.

3. Curves WL, Kiesslich R, Bergman JJGHM. Novel imaging modalities for detecting oesophageal neoplasia. Best Pract Res Clin Gastroenterol. 2008;22:687-720.

4. Dent J, El-Serag HB, Wallander MA, Johansson S. Epidemiology of gastrooesophageal reflux disease: a systematic review. Gut. 2005;54:710-7.

5. Falk GW, Fennerty MB, Rothstein RI. AGA Institute technical review on the use of endoscopic therapy for gastroesophageal reflux disease. Gastroenterology. 2006;131:1315-36.

6. Hongo M. Minimal changes in reflux esophagitis: red ones and white ones. J Gastroenterol. 2006;41:95-9.

7. Lee JH, Kim N, Chung IK, Jo YJ, Seo GS, Kim SW, Im EH, Kim HR, Park SH, Lee SY, Cha HM, Lee KS, Hyun DH, Kim HY, Kim SM, Shin JE, Park SH, Chung HC, Chung IS; H. pylori and GERD Study Group of Korean College of Helicobacter and Upper Gastrointestinal Research. Clinical significance of minimal change lesions of the esophagus in a healthy Korean population: a nationwide multi-center prospective study. J Gastroenterol Hepatol. 2008;23:1153-7.
8. Miwa H, Yokoyama T, Hori K, Sakagami T, Oshima T, Tomita T, Fujiwara Y, Saita H, Itou T, Ogawa H, Nakamura Y, Kishi K, Murayama Y, Hayashi E, Kobayashi K, Tano M, Matsushita K, Kawamoto H, Sawada Y, Ohkawa A, Arai E, Nagao K, Hamamoto N, Sugiyasu Y, Sugimoto K, Hara H, Tanimura M, Honda Y, Isozaki K, Noda S, Kubota S, Himeno S. Interobserver agreement in endoscopic evaluation of reflux esophagitis using a modified Los Angeles classification incorporating grades $\mathrm{N}$ and $\mathrm{M}$ : a validation study in a cohort of Japanese endoscopists. Dis Esophagus. 2008;21:355-63.

9. Moraes-Filho JP, Chinzon D, Eisig JN, Hashimoto CL, Zaterka S. Prevalence of heartburn and gastroesophageal reflux disease in the urban Brazilian population. Arq Gastroenterol. 2005;42:122-7.

10. Pohl J, May A, Rabenstein T, Pech O, Ell C. Computed virtual chromoendoscopy: a new tool for enhancing tissue surface structures. Endoscopy. 2007;39:80-3.

11. Stanghellini V. Relationship between upper gastrointestinal symptoms and lifestyle, psychosocial factors and comorbidity in the general population: results from the Domestic/International Gastroenterology Surveillance Study (DIGEST). Scand J Gastroenterol Suppl. 1999;231:29-37.

12. Vakil N, van Zanten SV, Kahrilas P, Dent J, Jones R. The Montreal definition and classification of gatroesophageal reflux disease: a global evidence-based consensus. Am J Gastroenterol. 2006;101:1900-20. 